\title{
Asuhan Keperawatan Jiwa Pada Ny. L Dengan Masalah Halusinasi Pendengaran
}

\author{
Marlina \\ Sinagamarlina29@gmail.com
}

\section{BAB I \\ PENDAHULUAN}

\subsection{Latar Belakang}

Gangguan jiwa yaitu suatu sindrom atau pola perilaku yang secara klinis bermakna yang berhubungan dengan distres atau penderitaan dan menimbulkan gangguan pada satu atau lebih fungsi kehidupan manusia (Keliat, 2014). Skizofrenia adalah sekelompok reaksi psikotik yang memengaruhi berbagai area fungsi individu, termasuk berpikir, berkomunikasi, menerima, menginterpretasikan realitas, merasakan dan menunjukkan emosi. Menambahkan definisi skizofrenia yaitu penyakit kronis, parah, dan melumpuhkan, gangguan otak yang ditandai dengan pikiran kacau, waham, halusinasi, dan perilaku aneh (Pardede, Keliat, \& Yulia, 2015). Pasien skizofrenia yang tidak teratur minum obat mengalami kekambuhan sebesar 74\%, di antaranya memerlukan rehospitalisasi sebasar 71\%. (Mubin \& Livana, 2019).

Skizofrenia menimbulkan distorsi pikiran, distorsi persepsi, emosi, dan tingkah laku sehingga pasien dengan skizofrenia memiliki risiko lebih tinggi berperilaku agresif di mana perubahan perilaku secara dramatis terjadi dalam beberapa hari atau minggu. Hal inilah yang membuat perlu bantuan keluarga untuk merawat dan memberikan perhatian khusus pada pasien skizofrenia (Pardede \& Siregar, 2016). Fenomena gangguan jiwa pada saat ini mengalami peningkatan yang sangat signifikan, dan setiap tahun di berbagai belahan dunia jumlah penderita gangguan jiwa bertambah. Berdasarkan data dari (WHO, 2013) ada sekitar 450 juta orang di dunia 
yang mengalami gangguan jiwa. Berdasarkan hasil penelitian dari (Pardede, \& Hasibuan, 2019).

Prevalensi masalah kesehatan jiwa di Indonesia di Indonesia, estimasi jumlah penderita skizofrenia mencapai sekitar 400.000 orang atau sebanyak 1,7 per 1.000 penduduk Riskesdas 2013, sedangkan Riskesdas 2018 juga menyebutkan sebanyak 84,9\% pengidap skizofrenia/psikosis di Indonesia telah berobat. Data dari 33 Rumah Sakit Jiwa ( RSJ ) yang ada di seluruh Indonesia menyebutkan hingga kini jumlah penderita gangguan jiwa berat mencapai 2,5 juta orang. Di Provinsi Sumatera Utara sendiri penderita skizofrenia menduduki peringkat ke 21 dengan nilai privlalensi 6,3.\%, setelah Provinsi Jawa Timur (Kemenkes, 2019).

Halusinasi adalah suatu gejala pada individu dengan gangguan jiwa yang mengalami gangguan perubahan persepsi sensori yang ditandai dengan klien merasakan sensasi berupa suara, penglihatan, pengecapan, perabaan, atau penghiduan tanpa stimulus yang nyata (Keliat, 2014). Halusinasi sudah melebur dan pasien merasa sangat ketakutan, panik dan tidak bisa membedakan antara khayalan dan kenyataan yang dialaminya (Nurlaili, 2019). Survei awal dilakukan di Yayasan Pemenang Jiwa Sumatra dengan jumlah pasien 70 orang tetapi yang menjadi subjek di dalam pembuatan askep ini berjumlah 1 orang dengan pasien masalah halusinasi pendengaran atas nama inisial Ny. L, penyebabnya Ny. L sebagai subjek di karenakan pasien belum bisa mengatasi halusinasinya selain minum obat. Maka tujuan asuhan keperawatan yang akan di lakukan ialah untuk mengajarkan standar pelaksanaan masalah halusinasi pendengaran pada saat Ny. L mengalami halusinasinya. 


\subsection{Tujuan}

\subsubsection{Tujuan Umum}

Mahasiswa mampu memberikan asuhan keperawatan secara holistik dan komprehensif kepada Ny. L dengan gangguan persepsi sensori : halusinasi pendengaran.

\subsubsection{Tujuan Khusus}

1. Mahasiswa mampu melakukan pengkajian pada Ny. L dengan gangguan persepsi sensori : halusinasi pendengaran.

2. Mahasiswa mampu menegakkan diagnosa keperawatan yang ada pada Ny. L dengan gangguan persepsi sensori : halusinasi pendengaran.

3. Mahasiswa menetapkan perencanaan keperawatan pada Ny. L dengan gangguan persepsi sensori : halusinasi pendengaran.

4. Mahasiswa melakukan implementasi keperawatan pada Ny. L dengan gangguan persepsi sensori : halusinasi pendengaran.

5. Mahasiswa mengevaluasi hasil asuhan keperawatan pada Ny. L dengan gangguan persepsi sensori : halusinasi pendengaran.

6. Mendokumentasikan asuhan keperawatan yang diberikan pada $\mathrm{Ny}$. L dengan gangguan persepsi sensori : halusinasi pendengaran. 


\section{BAB 2 \\ TINJAUAN TEORI}

\subsection{Konsep Dasar Halusinasi Pendengaran}

\subsubsection{Pengertian}

Halusinasi merupakan distrosi pesepsi yang tidak nyata dan terjadi pada respon neurobiologis maladaptive. Halusinasi yang dialami oleh individu dapat disebabkan melalui faktor presdisposisi dan presipitasi (Stuart, Keliat \& Pasaribu, 2016).

\subsubsection{Klasifikasi Halusinasi}

Menurut (Yusuf, 2015) klasifikasi halusinasi dibagi menjadi 5 yaitu :

\begin{tabular}{|c|c|c|c|}
\hline No & $\begin{array}{l}\text { Jenis } \\
\text { halusinasi }\end{array}$ & Data Objektif & Data Subjektif \\
\hline 1 & $\begin{array}{l}\text { Halusinasi } \\
\text { Pendengaran }\end{array}$ & $\begin{array}{l}\text { 1. Bicara atau } \\
\text { tertawa sendiri } \\
\text { tanpa lawan } \\
\text { bicara } \\
\text { 2. Marah-marah } \\
\text { tanpa sebab } \\
\text { mencondongkan } \\
\text { telinga ke arah } \\
\text { tertentu } \\
\text { 3. Menutup telinga }\end{array}$ & $\begin{array}{l}\text { 1. Mendengar suara } \\
\text { atau kegaduhan } \\
\text { 2. Mendengar suara } \\
\text { yang mengajak } \\
\text { bercakap-cakap } \\
\text { 3. Mendengar suara } \\
\text { yang menyuruh } \\
\text { melakukan sesuatu } \\
\text { yang berbahaya }\end{array}$ \\
\hline 2 & $\begin{array}{l}\text { Halusinasi } \\
\text { penglihatan }\end{array}$ & $\begin{array}{l}\text { 1. Menunjuk- } \\
\text { nunjuk ke arah } \\
\text { tertentu } \\
\text { 2. Ketakutan pada } \\
\text { objek yang tidak } \\
\text { jelas }\end{array}$ & $\begin{array}{l}\text { 1. Melihat bayangan, } \\
\text { sinar, bentuk } \\
\text { geometris, bentuk } \\
\text { kartun, melihat } \\
\text { hantu atau monster }\end{array}$ \\
\hline 3 & $\begin{array}{l}\text { Halusinasi } \\
\text { penghindu }\end{array}$ & $\begin{array}{l}\text { 1. Menghindu } \\
\text { seperti sedang } \\
\text { membaui bau- }\end{array}$ & $\begin{array}{l}\text { 1. Membaui bau-bauan } \\
\text { seperti bau darah, } \\
\text { urine, feses, }\end{array}$ \\
\hline
\end{tabular}




\begin{tabular}{|c|c|c|c|}
\hline & & $\begin{array}{l}\text { bauan tertentu } \\
\text { 2. Menutup hidung }\end{array}$ & $\begin{array}{l}\text { 2. kadang-kadang bau } \\
\text { itu menyenangkan }\end{array}$ \\
\hline 4 & $\begin{array}{l}\text { Halusinasi } \\
\text { pengecepan }\end{array}$ & $\begin{array}{l}\text { 1. Sering meludah } \\
\text { 2. Muntah }\end{array}$ & $\begin{array}{l}\text { 1. Merasakan rasa } \\
\text { seperti darah, urine, } \\
\text { feses }\end{array}$ \\
\hline 5 & $\begin{array}{l}\text { Halusinasi } \\
\text { perabaan }\end{array}$ & $\begin{array}{l}\text { Menggaruk-garuk } \\
\text { permukaan kulit }\end{array}$ & $\begin{array}{l}\text { 1. Mengatakan ada } \\
\text { serangga di } \\
\text { permukaan kulit } \\
\text { 2. Merasa seperti } \\
\text { tersengat listrik }\end{array}$ \\
\hline
\end{tabular}

\subsubsection{Tanda dan Gejala}

Tanda dan gejala halusinasi dinilai dari hasil observasi terhadap pasien serta ungkapan pasien menurut (Oktiviani, 2020) :

1. Menyeringai atau tertawa yang tidak sesuai

2. Menggerakkan bibirnya tanpa menimbulkan suara

3. Gerakan mata cepat

4. Menutup telinga

5. Respon verbal lambat atau diam

6. Diam dan dipenuhi oleh sesuatu yang mengasyikkan

7. Terlihat bicara sendiri

8. Menggerakkan bola mata dengan cepat

9. Bergerak seperti membuang atau mengambil sesuatu

10. Duduk terpaku, memandang sesuatu, tiba-tiba berlari ke ruangan lain

11. Disorientasi (waktu, tempat, orang)

12. Perubahan kemampuan dan memecahkan masalah

13. Perubahan perilaku dan pola komunikasi

14. Gelisah, ketakutan, ansietas

15. Peka rangsang

16. Melaporkan adanya halusinasi 


\subsubsection{Etiologi}

Faktor predisposisi klien halusinasi menurut (Oktiviani, 2020) :

1. Faktor Predisposisi

a. Faktor perkembangan

Tugas perkembangan klien terganggu misalnya rendahnya kontrol dan kehangatan keluarga menyebabkan klien tidak mampu mandiri sejak kecil, mudah frustasi, hilang percaya diri.

b. Faktor sosiokultural

Seseorang yang merasa tidak diterima dilingkungan sejak bayi akan merasa disingkirkan, kesepian, dan tidak percaya pada lingkungan.

c. Biologis

Faktor biologis Mempunyai pengaruh terhadap terjadinya gangguan jiwa. Adanya stress yang berlebihan dialami seseorang maka didalam tubuh akan dihasilkan suatu zat yang dapat bersifat halusinogen neurokimia.Akibat stress berkepanjangan menyebabkan teraktivasinya neurotransmitter otak.

d. Psikologis

Tipe kepribadian lemah dan tidak bertanggung jawab mudah terjerumus pada penyalahgunaan zat adikitif. Hal ini berpengaruh pada ketidakmampuan klien dalam mengambil keputusan yang tepat demi masa depannya, klien lebih memilih kesenangan sesaat dan lari dari alam nyata menuju alam khayal.

e. Sosial Budaya

Meliputi klien mengalami interaksi sosial dalam fase awal dan comforting, klien meganggap bahwa hidup bersosialisasi di alam nyata sangat membahayakan. Klien asyik dengan Halusinasinya, seolah-olah ia merupakan tempat untuk 
memenuhi kebutuhan akan interaksi sosial, kontrol diri dan harga diri yang tidak didapatkan dakam dunia nyata.

\section{Faktor Presipitasi}

Faktor presipitasi merupakan stimulus yang dipersepsikan oleh individu sebagai tantangan, ancaman, atau tuntutan yang memerlukan energi ekstra untuk menghadapinya. Seperti adanya rangsangan dari lingkungan, misalnya partisipasi klien dalam kelompok, terlalu lama tidak diajak komunikasi, objek yang ada di lingkungan dan juga suasana sepi atau terisolasi, sering menjadi pencetus terjadinya halusinasi. Hal tersebut dapat meningkatkan stress dan kecemasan yang merangsang tubuh mengeluarkan zat halusinogenik. Penyebab Halusinasi dapat dilihat dari lima dimensi (Oktiviani, 2020) yaitu :

a. Dimensi fisik: Halusinasi dapat ditimbulkan oleh beberapa kondisi fisik seperti kelelahan yang luar biasa, penggunaaan obatobatan, demam hingga delirium, intoksikasi alkohol dan kesulitan untuk tidur dalam waktu yang lama.

b. Dimensi Emosional: Perasaan cemas yang berlebihan atas dasar problem yang tidak dapat diatasi merupakan penyebab halusinasi itu terjadi. Isi dari halusinasi dapat berupa perintah memaksa dan menakutkan. Klien tidak sanggup lagi menentang perintah tersebut hingga dengan kondisi tersebut klien berbuat sesuatu terhadap ketakutan tersebut.

c. Dimensi Intelektual: Dalam dimensi intelektual ini menerangkan bahwa individu dengan halusinasi akan memperlihatkan adanya penurunan fungsi ego. Pada awalnya halusinasi merupakan usaha dari ego sendiri untuk melawan impuls yang menekan, namun merupakan suatu hal yang menimbulkan kewaspadaan yang dapat mengambil seluruh perhatian klien dan tidak jarang akan mengontrol semua perilaku klien.

d. Dimensi Sosial: Klien mengalami interaksi sosial dalam fase awal dan comforting, klien meganggap bahwa hidup bersosialisasi di 
alam nyata sangat membahayakan. Klien asyik dengan Halusinasinya, seolah-olah ia merupakan tempat untuk memenuhi kebutuhan akan interaksi sosial, kontrol diri dan harga diri yang tidak didapatkan dakam dunia nyata.

e. Dimensi Spiritual: Secara sepiritual klien Halusinasi mulai dengan kehampaan hidup, rutinitas tidak bermakna, hilangnya aktifitas ibadah dan jarang berupaya secara sepiritual untuk menyucikan diri. Saat bangun tidur klien merasa hampa dan tidak jelas tujuan hidupnya. Individu sering memaki takdir tetapi lemah dalam upaya menjemput rezeki, menyalahkan lingkungan dan orang lain yang menyebabkan takdirnya memburuk.

\begin{tabular}{|c|c|c|}
\hline Adaptif & Mal Adapt & \\
\hline $\begin{array}{lr}\text { Pikiran logis } & \text { Persepsi } \\
\text { akurat emosi } & \text { kosisten } \\
\text { dengan pengalaman } \\
\text { perilaku } & \text { sesuai } \\
\text { hubungan social } & \end{array}$ & $\begin{array}{lr}\text { Distorsi pikiran } \\
\text { (pikiran kotor) Ilusi } \\
\text { Reaksi } \\
\text { berlebih emosi } \\
\text { kurang atau } \\
\text { aneh dan tidak bisa } \\
\text { menarik diri }\end{array}$ & $\begin{array}{l}\text { Gangguan } \\
\text { pikir/delusi } \\
\text { Halusinasi Perilaku } \\
\text { disorganisasi } \\
\text { Isolasi sosial }\end{array}$ \\
\hline
\end{tabular}

1. Respon Adaptif

Respon adaptif respon yang dapat diterima oleh norma-norma sosial budaya yang berlaku. Dengan kata lain individu tersebut dalam batas normal jika menghadapi suatu masalah akan dapat memecahkan masalah tersebut, respon adaftif :

a. Pikiran logis adalah pandangan yang mengarah pada kenyataan. Persepsi akurat adalah pandangan yang tepat pada kenyataan.

b. Emosi konsisten dengan pengalaman yaitu perasaan yang timbul dari pengalaman

c. Perilaku sosial adalah sikap dan tingkah laku yang masih dalam batas kewajaran. 
d. Hubungan sosial adalah proses suatu interaksi dengan orang lain dan lingkungan.

2. Respon Maladaptif

Respon maladaptif adalah respon individu dalam menyelesaikan masalah yang menyimpang dari norma-norma sosial budaya dan lingkungan, adapun respon maladaptif meliputi:

a. Kelainan pikiran adalah keyakianan yang secara kokoh dipertahankan walaupun tidak diyakini oleh orang lain dan bertetangan dengan kenyataan sosial.

b. Halusinasi merupakan persepsi sensori yang salah atau persepsi eksternal yang tidak realita atau tidak ada.

c. Kerusakan proses emosi adalah perubahan sesuatu yang timbul dari hati.

d. Perilaku tidak terorganisir merupakan suatu yang tidak teratur.

e. Isolasi sosial adalah kondisi kesendirian yang dialami oleh individu dan diterima sebagai ketentuan oleh orang lain dan sebagai suatu kecelakaan yang negatif mengancam.

\subsubsection{Fase Halusinasi}

Halusinasi terbagi atas beberapa fase (Oktiviani, 2020):

a. Fase Pertama / Sleep disorder

pada fase ini Klien merasa banyak masalah, ingin menghindar dari lingkungan, takut diketahui orang lain bahwa dirinya banyak masalah. Masalah makin terasa sulit karna berbagai stressor terakumulasi, misalnya kekasih hamil, terlibat narkoba, dikhianati kekasih, masalah dikampus, drop out, dst. Masalah terasa menekan karena terakumulasi sedangkan support sistem kurang dan persepsi terhadap masalah sangat buruk. Sulit tidur berlangsung trus-menerus sehingga terbiasa menghayal. Klien menganggap lamunanlamunan awal tersebut sebagai pemecah masalah

b. Fase Kedua / Comforting 
Klien mengalami emosi yang berlanjut seperti adanya perasaan cemas, kesepian, perasaan berdosa, ketakutan, dan mencoba memusatkan pemikiran pada timbulnya kecemasan. Ia beranggapan bahwa pengalaman pikiran dan sensorinya dapat dia kontrol bila kecemasannya diatur, dalam tahap ini ada kecenderungan klien merasa nyaman dengan halusinasinya

c. Fase Ketiga / Condemning

Pengalaman sensori klien menjadi sering datang dan mengalami bias. Klien mulai merasa tidak mampu lagi mengontrolnya dan mulai berupaya menjaga jarak antara dirinya dengan objek yang dipersepsikan klien mulai menarik diri dari orang lain, dengan intensitas waktu yang lama.

d. Fase Keempat / Controlling Severe Level of Anxiety

Klien mencoba melawan suara-suara atau sensori abnormal yang datang. Klien dapat merasakan kesepian bila halusinasinya berakhir. Dari sinilah dimulai fase gangguan psikotik.

e. Fase ke lima / Conquering Panic Level of Anxiety Pengalaman sensorinya terganggu. Klien mulai terasa terancam dengan datangnya suara-suara terutama bila klien tidak dapat menuruti ancaman atau perintah yang ia dengar dari halusinasinya. Halusinasi dapat berlangsung selama minimal empat jam atau seharian bila klien tidak mendapatkan komunikasi terapeutik. Terjadi gangguan psikotik berat.

\subsubsection{Penatalaksanaan Medis}

Halusinasi merupakan salah satu gejala yang paling sering terjadi pada gangguan Skizofrenia. Dimana Skizofrenia merupakan jenis psikosis, adapun tindakan penatalaksanaan dilakukan dengan berbagai terapi (Pardede, Keliat, \& Wardani, 2013) yaitu :

1. Psikofarmakologis

Obat sangat penting dalam pengobatan skizofrenia, karena obat dapat membantu pasien skizofrenia untuk meminimalkan gejala 
perilaku kekerasan, halusinasi, dan harga diri rendah. Sehingga pasien skizofrenia harus patuh minum obat secara teratur dan mau mengikuti perawatan.

a. Haloperidol (HLD)

Obat yang dianggap sangat efektif dalam pengelolaan hiperaktivitas, gelisah, agresif, waham, dan halusinasi.

b. Chlorpromazine (CPZ)

Obat yang digunakan untuk gangguan psikosis yang terkait skizofrenia dan gangguan perilaku yang tidak terkontrol

c. Trihexilpenidyl (THP)

Obat yang digunakan untuk mengobati semua jenis parkinson dan pengendalian gejala ekstrapiramidal akibat terapi obat.

1. Dosis

a) Haloperidol $3 \times 5 \mathrm{mg}$ (tiap 8 jam) intra muscular.

b) Clorpromazin $25-50 \mathrm{mg}$ diberikan intra muscular setiap 6-8 jam sampai keadaan akut teratasi.

2. Dalam keadaan agitasi dan hiperaktif diberikan tablet:
a) Haloperidol $2 \times 1,5-2,5 \mathrm{mg}$ per hari.
b) Klorpromazin 2x100 mg per hari
c) Triheksifenidil $2 \times 2 \mathrm{mg}$ per hari

3. Dalam keadaan fase kronis diberikan tablet:
a) Haloperidol 2x0,5 - $1 \mathrm{mg}$ perhari
b) Klorpromazin 1x50 mg sehari (malam)
c) Triheksifenidil 1-2x2 mg sehari
d) Psikosomatik

2. Terapi kejang listrik (Electro Compulsive Therapy), yaitu suatu terapi fisik atau suatu pengobatan untuk menimbulkan kejang grand mal secara artifisial dengan melewatkan aliran listrik melalui elektroda yang dipasang pada satu atau dua temples pada pelipis. Jumlah tindakan yang dilakukan merupakan rangkaian yang bervariasi pada setiap pasien tergantung pada masalah pasien dan respon terapeutik sesuai hasil pengkajian 
selama tindakan. Pada pasien Skizofrenia biasanya diberikan 30 kali. ECT biasanya diberikan 3 kali seminggu walaupun biasanya diberikan jarang atau lebih sering. Indikasi penggunaan obat: penyakit depresi berat yang tidak berespon terhadap obat, gangguan bipolar di mana pasien sudah tidak berespon lagi terhadap obat dan pasien dengan bunuh diri akut yang sudah lama tidak mendapatkan pertolongan.

\section{Psikoterapi}

Membutuhkan waktu yang relatif lama, juga merupakan bagian penting dalam proses terapeutik. Upaya dalam psikoterapi ini meliputi: memberikan rasa aman dan tenang, menciptakan lingkungan terapeutik, memotivasi klien untuk dapat mengungkapkan perasaan secara verbal, bersikap ramah, sopan, dan jujur terhadap klien.

\subsubsection{Komplikasi}

Halusinasi dapat menjadi suatu alasan mengapa klien melakukan tindakan perilaku kekerasan karena suara-suara yang memberinya perintah sehingga rentan melakukan perilaku yang tidak adaptif. Perilaku kekerasan yang timbul pada klien skizofrenia diawali dengan adanya perasaan tidak berharga, takut dan ditolak oleh lingkungan sehingga individu akan menyingkir dari hubungan interpersonal dengan orang lain,komplikasi yang dapat terjadi pada klien dengan masalah utama gangguan sensori persepsi: halusinasi, antara lain: resiko prilaku kekerasan, harga diri rendah dan isolasi sosial (Keliat, 2014). 


\subsection{Konsep Dasar Asuhan Keperawatan}

\subsubsection{Pengkajian Keperawatan}

Menurut (Keliat, 2014). Bahwa faktor-faktor terjadinya halusinasi meliputi:

1. Faktor predisposisi

a. Faktor biologis

Pada keluarga yang melibatkan anak kembar dan anak yang diadopsi menunjukkan peran genetik pada schizophrenia.Kembar identik yang dibesarkan secara terpisah mempunyai angka kejadian Schizophrenia lebih tinggi dari pada saudara sekandung yang dibesarkan secara terpisah.

b. Faktor psikologis

Hubungan interpersonal yang tidak harmonis akan mengakibatkan stress dan kecemasan yang berakhir dengan gangguan orientasi realita.

c. Faktor sosial budaya

Stress yang menumpuk awitan schizophrenia dan gangguan psikotik lain, tetapi tidak diyakini sebagai penyebab utama gangguan.

2. Faktor presipitasi

b. Biologis

Stressor biologis yang berhubungan dengan respon neurobiologis maladaptif adalah gangguan dalam komunikasi dan putaran umpan balik otak dan abnormalitas pada mekanisme pintu masuk dalam otak, yang mengakibatkan ketidakmampuan untuk secara selektif menanggapi stimulus.

c. Lingkungan

Ambang toleransi terhadap stres yang ditentukan secara biologis berinteraksi dengan stresor lingkungan untuk menentukan terjadinya gangguan prilaku. 
d. Stres sosial / budaya

Stres dan kecemasan akan meningkat apabila terjadi penurunan stabilitas keluarga, terpisahnya dengan orang terpenting atau disingkirkan dari kelompok.

e. Faktor psikologik

Intensitas kecemasan yang ekstrem dan memanjang disertai terbatasnya kemampuan mengatasi masalah dapat menimbulkan perkembangan gangguan sensori persepsi halusinasi.

f. Mekanisme koping

Perilaku yang mewakili upaya untuk melindungi pasien dari pengalaman yang menakutkan berhubungan dengan respons neurobiologis maladaptif meliputi : regresi, berhunbungan dengan masalah proses informasi dan upaya untuk mengatasi ansietas, yang menyisakan sedikit energi untuk aktivitas sehari-hari. Proyeksi, sebagai upaya untuk menejlaskan kerancuan persepsi dan menarik diri.

g. Sumber koping

Sumber koping individual harus dikaji dengan pemahaman tentang pengaruh gangguan otak pada perilaku. Orang tua harus secara aktif mendidik anak-anak dan dewasa muda tentang keterampilan koping karena mereka biasanya tidak hanya belajar dari pengamatan. Disumber keluarga dapat pengetahuan tentang penyakit, finensial yang cukup, faktor ketersediaan waktu dan tenaga serta kemampuan untuk memberikan dukungan secara berkesinambungan.

h. Perilaku halusinasi

Batasan karakteristik halusinasi yaitu bicara teratawa sendiri, bersikap seperti memdengar sesuatu, berhenti bicara 
ditengah - tengah kalimat untuk mendengar sesuatu, disorientasi, pembicaraan kacau dan merusak diri sendiri, orang lain serta lingkungan.

\subsubsection{Diagnosa Keperawatan}

Menurut NANDA 2015-2017 yakni gangguan persepsi. Dengan faktor berhubungan dan batasan karakteristik disesuaikan dengan keadaan yang ditemukan pada tiap-tiap partisipan. Topik yang diteliti yakni kemampuan mengontrol halusinasi dengar (Aji, 2019).

\subsubsection{Perencanaan Keperawatan}

Rencana tindakan pada keluarga (Keliat, 2014) adalah ;

1. Diskusikan masalah yang dihadap keluarga dalam merawat pasien

2. Berikan penjelasan meliputi : pengertian halusinasi, proses terjadinya halusinasi, jenis halusinasi yang dialami, tanda dan gejala halusinasi, proses terjadinya halusinasi.

3. Jelaskan dan latih cara merawat anggota keluarga yang mengalami halusinasi : menghardik, minum obat, bercakapcakap, melakukan aktivitas.

4. Diskusikan cara menciptakan lingkungan yang dapat mencegah terjadinya halusinasi.

5. Diskusikan tanda dan gejala kekambuhan

6. Diskusikan pemanfaatan fasilitas pelayanan kesehatan terdekat untuk follow up anggota keluarga dengan halusinasi.

Rencana tindakan keperawatan pada klien dengan diagnosa gangguan persepsi sensori halusinasi meliputi pemberian tindakan keperawatan berupa terapi (Sulah, Pratiwi, \& Teguh. 2016) yaitu :

1. Bantu klien mengenal halusinasinya meliputio isi, waktu terjadi halusinasi, isi, frekuensi, perasaan saat terjadi halusinasi respon klien terhadap halusinasi mengontrol halusinasi dengan cara menghardik,

2. meminum obat secara teratur. 
3. Melatih bercakap-cakap dengan orang lain,

4. Menyusun kegiatan terjadwal dan dengan aktifitas

\subsubsection{Implementasi}

Implementasi disesuaikan dengan rencana tindakan keperawatan. Pada situasi nyata sering pelaksanaan jauh berbeda dengan rencana, hal ini terjadi karena perawat belum terbiasa menggunakan rencana tertulis dalam melaksanakan tindakan keperawatan. Sebelum melaksanakan tindakan keperawatan yang sudah direncanakan, perawat perlu memvalidasi dengan singkat apakah rencana tindakan masih sesuai dan dibutuhkan klien sesuai dengan kondisinya (here and now). Perawat juga menilai diri sendiri, apakah kemampuan interpersonal, intelektual, tekhnikal sesuai dengan tindakan yang akan dilaksanakan, dinilai kembali apakah aman bagi klien. Setelah semuanya tidak ada hambatan maka tindakan keperawatan boleh dilaksanakan.

Adapun pelaksanaan tindakan keperawatan jiwa dilakukan berdasarkan Strategi Pelaksanaan (SP) yang sesuai dengan masingmasing masalah utama. Pada masalah gangguan sensori persepsi: halusinasi pendengaran, terdapat 2 jenis SP, yaitu SP Klien dan SP Keluarga.SP klien terbagi menjadi SP 1 (membina hubungan saling percaya, mengidentifikasi halusinasi "jenis, isi, waktu, frekuensi, situasi, perasaan dan respon halusinasi”, mengajarkan cara menghardik, memasukan cara menghardik ke dalam jadwal; SP 2 (mengevaluasi SP 1, mengajarkan cara minum obat secara teratur, memasukan ke dalam jadwal); SP 3 (mengevaluasi SP 1 dan SP 2, menganjurkan klien untuk mencari teman bicara); SP 4 (mengevaluasi SP 1, SP 2, dan SP 3, melakukan kegiatan terjadwal).

SP keluarga terbagi menjadi SP 1 (membina hubungan saling percaya, mendiskusikan masalah yang dihadapi keluarga dalam 
merawat pasien, menjelaskan pengertian, tanda dan gejala helusinasi, jenis halusinasi yang dialami klien beserta proses terjadinya, menjelaskan cara merawat pasien halusinasi); SP 2 (melatih keluarga mempraktekan cara merawat pasien dengan halusinasi, melatih keluarga melakukan cara merawat langsung kepada pasien halusinasi); SP 3 (membantu keluarga membuat jadwal aktivitas di rumah termasuk minum obat (discharge planing), menjelaskan follow up pasien setelah pulang).

Pada saat akan dilaksanakan tindakan keperawatan maka kontrak dengan klien dilaksanakan dengan menjelaskan apa yang akan dikerjakan dan peran serta klien yang diharapkan, dokumentasikan semua tindakan yang telah dilaksanakan serta respon klien.

\subsubsection{Evaluasi Keperawatan}

Evaluasi adalah proses hasil atau sumatif dilakukan dengan membandingkan respon klien pada tujuan umum dan tujuan khusus yang telah ditentukan.halusinasi pendengaran tidak terjadi perilaku kekerasan, klien dapat membina hubungan saling percaya, klien dapat mengenal halusinasinya, klien dapat mengontrol halusinasi dengar dari jangka waktu 4x24 jam didapatkan data subjektif keluarga menyatakan senang karena sudah diajarkan teknik mengontrol halusinasi, keluarga menyatakan pasien mampu melakukan beberapa teknik mengontrol halusinasi. Data objektif pasien tampak berbicara sendiri saat halusinasi itu datang, pasien dapat berbincang-bincang dengan orang lain, pasien mampu melakukan aktivitas terjadwal, dan minum obat secara teratur ( Aji, 2019) 


\subsection{Identitas Klien}

\section{BAB 3 \\ TINJAUAN KASUS}

Inisial

Ruang Rawat

Tanggal Pengkajian

Umur

Agama

Informan
: Ny. L

: Yayasan pemenang jiwa sumatera utara

: 16 februari 2021

: 53 Tahun

: Buddha

: Klien dan Status Klien

\subsection{Alasan Masuk}

Klien Awalnya marah-marah karena kesal, melamun, sering bicara sendiri, mondar mandir, mendengar suara-suara tanpa wujud, tertawa sendiri.

\subsection{Faktor Predisposisi}

Klien sebelumnya pernah mengalami gangguan jiwa \pm 6 bulan yang lalu tepatnya pada tahun 2021 dan pulang kerumah dalam keadaan tenang. Dirumah klien tidak rutin minum obat, tidak mau kontrol ke RSJ sehingga timbul gejala-gejala seperti diatas kemudian klien kambuh lagi. Klien awalnya marah-marah dan melempar barang-barang karena kesal, suka menyendiri, melamun, sering bicara sendiri, mondar mandir, mendengar suara-suara tanpa wujud, tertawa sendiri akhirnya keluarga membawa klien kembali di Yayasan Pemenang Jiwa Provinsi Sumatera Utara pada tanggal 20 Januari 2021. Keluarga klien tidak ada yang pernah mengalami gangguan jiwa.

\subsection{Fisik}

Klien tidak memiliki keluhan fisik, saat dilakukan pemeriksaan tanda-tanda vital, didapatkan hasil TD : 110/80 mmHg ; N : 82x/i ; S : 36,5 ${ }^{\circ} \mathrm{C} ; \mathrm{P}: 20 \mathrm{x} / \mathrm{i}$. Klien memiliki tinggi badan $168 \mathrm{~cm}$ dan berat badan $67 \mathrm{Kg}$. 


\subsection{Psikososial}

\subsubsection{Genogram}

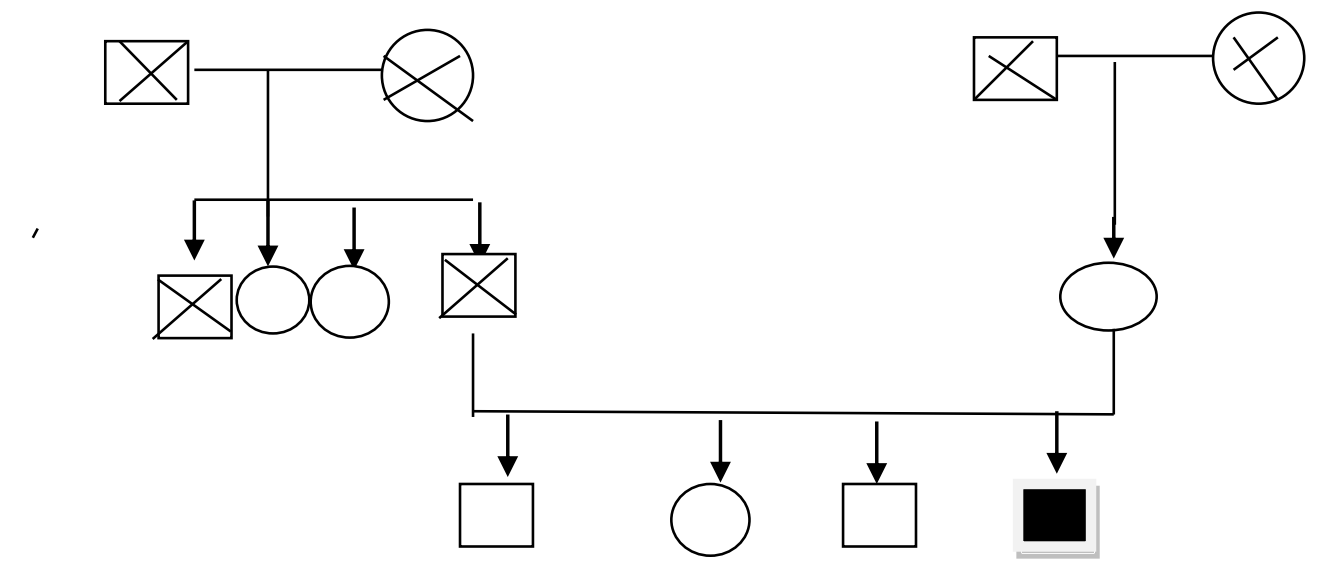

Penjelasan :

Klien merupakan anak keempat dari 4 bersaudara, klien memiliki 2 abang dan 1 kakak perempuan. Klien belum menikah.

Keterangan :

$\square$ : Laki-laki

$\bigcirc$ : Perempuan

: Klien

---- : Tinggal dalam satu rumah

$\searrow$ : meninggal

\subsubsection{Konsep diri}

a. Gambaran diri : Klien menyukai seluruh tubuhnya dan tidak ada yang cacat

b. Identitas : Klien anak ke 4 dari 4 bersaudara.

c. Peran : Klien hanya lulusan SMA yang saat ini tidak memiliki pekerjaan

d. Ideal diri $\quad$ : Klien merasa malu karena klien dirawat di RSJ dan ingin cepat pulang ke rumah. 
e. Harga diri : Klien mengatakan merasa malu berada di rumah sakit jiwa dan merasa bosan.

\subsubsection{Hubungan social}

Klien mengganggap bahwa keluarganya adalah orang yang sangat berarti dalam hidupnya, terutama orangtuanya. Klien mengatakan tidak mengikuti kegiatan di kelompok/masyarakat. Klien mengatakan mempunyai hambatan dalam berhubungan dengan orang lain karena klien sulit bergaul dan selalu ingin menyendiri.

\subsubsection{Spiritual}

a. Nilai dan Keyakinan: Klien beragama kristen dan yakin dengan agamanya.

b. Kegiatan Ibadah : Klien melakukan ibadah selama dirawat.

\subsubsection{Status Mental}

1. Penampilan pasien rapi seperti berpakaian biasa pada umum nya.

2. Pembicaraan

Klien bicara dengan lambat.

3. Aktivitas Motorik

Klien mengatakan bisa melakukan aktivitas sehari - hari.

4. Suasana perasaan

kliien tidak mampu mengepresikan perasaan nya pada saat mendengarkan suara - suara.

Masalah keperawatan ; Gangguan Sensori Persepsi : Halusinas

5. Afek

Penjelasan :efek wajah sesuai dengan topik pembicaraan

6. Interaksi selama wawancara

Penjelasan :Klien kooperatif saat wawancara

7. Persepsi 
Penjelasan :Klien mengatakan bahwa ia mendengar ada suarasuara

Masalah keperawatan : Gangguan persepsi sensori : halusinasi

8. Proses Pikir

Penjelasan : Klien mampu menjawab apa yang ditanya dengan

9. Isi piker

Penjelasan :Klien dapat mengontrol isi pikirnya,klien tidak mengalami gangguan isi pikir dan tidak ada waham. Klien tidak mengalami fobia, obsesi ataupun depersonalisasi.

10. Tingkat kesadaran

Penjelasan :Klien tidak mengalami gangguan orientasi, klien mengenali waktu, orang dan tempat.

11. Memori

Penjelasan :Klien mampu menceritakan kejadian di masa lalu dan yang baru terjadi.

12. Tingkat konsentrasi berhitung

Penjelasan: Klien mampu berkonsentrasi dalam perhitungan sederhana tanpa bantuan orang lain.

13. Kemampuan penilaian

Penjelasan : Klien dapat membedakan hal yang baik dan yang buruk (mampu melakukan penilaian)

14. Daya tilik diri

Penjelasan: Klien tidak mengingkari penyakit yang diderita, klien mengetahui bahwa dia sedang sakit dan dirawat di rumah sakit jiwa.

\subsection{Mekanisme Koping}

Klien mengalami mekanisme koping adaptif yaitu klien dapat berbicara baik dengan orang lain. 


\subsection{Masalah Psikososial dan Lingkungan}

Klien mengatakan sulit berteman dengan orang lain karena klien selalu ingin menyendiri.

\subsection{Pengetahuan Kurang Tentang Gangguan Jiwa}

Klien tidak mengetahui tentang gangguan jiwa yang di alaminya dan obat yang dikonsumsinya.

\subsection{Aspek Medik}

Diagnosa medis : Skizofrenia Paranoid

Terapi medis yang diberikan:

a. Resperidon tablet $2 \mathrm{mg} 2 \times 1$

\subsection{Analisa Data}

\begin{tabular}{|c|c|c|}
\hline No & Data & Masalah keperawatan \\
\hline 1 & $\begin{array}{l}\text { Ds } \\
\text { - Klien merasa tidak berguna } \\
\text { karena tidak dapat membantu } \\
\text { keluarga } \\
\text { - Klien merasa minder karena } \\
\text { penyakit yang di alaminya } \\
\text { - Klien sedih berada di yayasan } \\
\text { pemenang jiwa } \\
\text { Do : } \\
\text { - Klien tampak murung } \\
\text { - Lebih banyak diam } \\
\text { - Nada bicara pelan }\end{array}$ & $\begin{array}{l}\text { Gangguan konsep diri : } \\
\text { harga diri rendah kronis }\end{array}$ \\
\hline 2 & $\begin{array}{l}\text { Ds : } \\
\text { - Keluarga klien mengatakan } \\
\text { bahwa klien sering berteriak } \\
\text { - Klien sering mendengarkan } \\
\text { suara - suara tampa wajah }\end{array}$ & $\begin{array}{l}\text { Gangguan persepsi sensori } \\
\text { : halusinasi pendengaran }\end{array}$ \\
\hline
\end{tabular}




\begin{tabular}{|c|c|c|}
\hline & $\begin{array}{l}\text { yang menyuruhnya untuk } \\
\text { selalu ibadah } \\
\text { - Klien mengatakan suara - suara } \\
\text { tersebut muncul } 3 \text { kali / hari, } \\
\text { muncul pada saat klien sedang } \\
\text { menyendiri } \\
\text { - Klien merasa gelisah dan takut } \\
\text { jika mendengar suara tersebut } \\
\text { Do : } \\
\text { - Klien sering marah - marah, } \\
\text { mondar - mandir, bicara } \\
\text { sendiri, bicara ngawur, sering } \\
\text { senyum - senyum sendiri }\end{array}$ & \\
\hline 3 & $\begin{array}{l}\text { Ds : } \\
\text { Klien mengatakan tidak mengikuti } \\
\text { kegiatan di kelompok/masyarakat. } \\
\text { Klien mengatakan mempunyai } \\
\text { hambatan dalam berhubungan } \\
\text { dengan orang lain karena klien sulit } \\
\text { bergaul dan selalu ingin } \\
\text { menyendiri. } \\
\text { Do : } \\
\text { Klien tampak menghindari } \\
\text { interaksi, terlihat sedih, pendangan } \\
\text { menunduk kebawah }\end{array}$ & $\begin{array}{l}\text { Isolasi Sosial : Menarik } \\
\text { Diri }\end{array}$ \\
\hline
\end{tabular}

\subsection{Masalah Keperawatan}

1. Gangguan Persepsi Sensori : Halusinasi Pendengaran

2. Gangguan Konsep Diri : Harga Diri Rendah

3. Isolasi Sosial: Menarik Diri 


\subsection{Pohon Masalah}

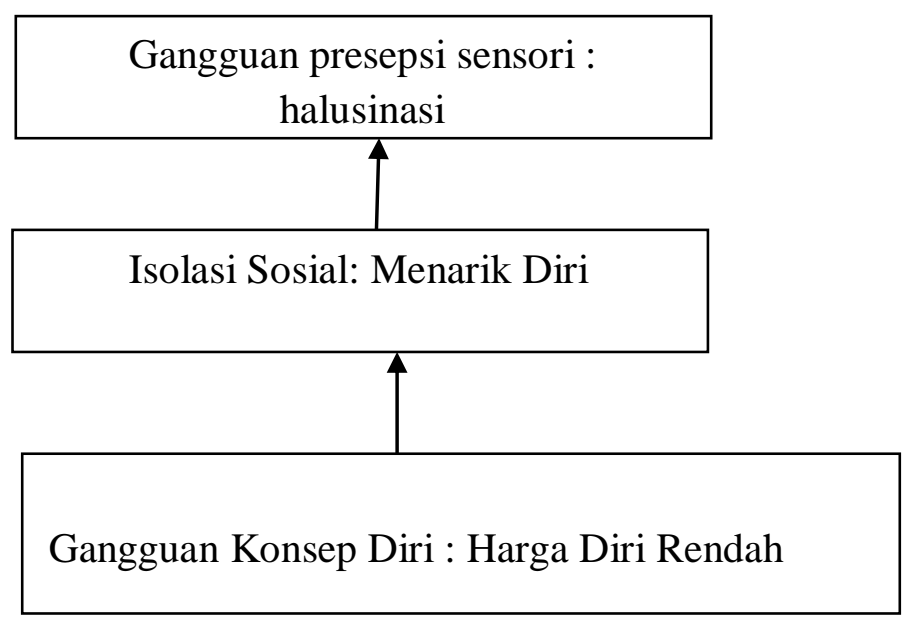

\subsection{Diagnosa Keperawatan}

1. Gangguan persepsi Sensorik : Halusinasi pendengaran

\subsection{Intervensi Keperawatan}

\begin{tabular}{|c|c|c|}
\hline No & Diagnosa & Intervensi \\
\hline 1. & $\begin{array}{l}\text { DO: } \\
\text { - Klien sering marah - } \\
\text { marah, mondar - } \\
\text { mandir, berbicara } \\
\text { sendiri, berbicara } \\
\text { ngawur, sering senyum- } \\
\text { senyum sendiri. } \\
\text { DS: } \\
\text { - Keluarga } \\
\text { mengatakan bahwa } \\
\text { klien sering berteriak - } \\
\text { teriak di rumah } \\
\text { - Klien sering } \\
\text { mendengarkan suara - }\end{array}$ & $\begin{array}{l}\text { SP 2: } \\
\text { Mengontrol Halusinasi dengan } \\
\text { cara minum obat secara teratur } \\
\text { SP 3: } \\
\text { mengontrol halusinasi dengan } \\
\text { cara bercakap - cakap dengan } \\
\text { orang lain }\end{array}$ \\
\hline
\end{tabular}




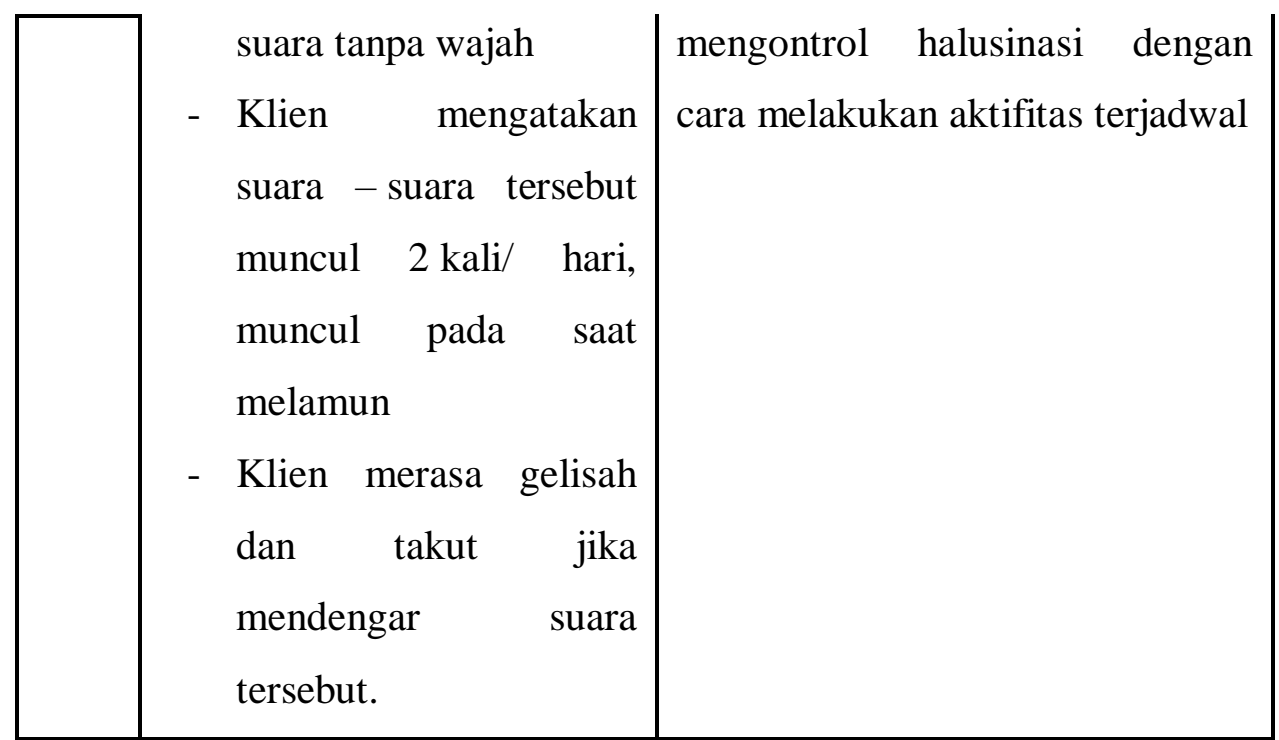




\subsection{Implementasi dan Evaluasi}

\begin{tabular}{|c|c|c|}
\hline WAKTU & Implemtasi & Evaluasi \\
\hline $\begin{array}{l}\text { Senin,15 } \\
\text { Februari } \\
2021 \\
\text { Jam 10: } 45 \\
\text { wib }\end{array}$ & $\begin{array}{l}\text { 1. Data } \\
\text { Tanda dan gejala :bicara } \\
\text { sendiri, marah - marah tampa } \\
\text { sebab, memalingkan muka ke } \\
\text { arah telingga, ketakutan pada } \\
\text { suatu yang tidak jelas, } \\
\text { 2.Diagnosa Keperawatan } \\
\text { Husinasi pendengaran } \\
\text { 3.Tindakan Keperawatan } \\
\text { Sp1 halusinasi } \\
\text { - Melatih } \\
\text { mengidentifikasi } \\
\text { halusinasinya; } \\
\text { frekuensi, watu terjadi, } \\
\text { dengan cara minum obat } \\
\text { dengan cara bercakap - cakap pencetus, perasaan } \\
\text { dan respon halusinasi } \\
\text { 4.RTL hengontrol halusinasi } \\
\text { dengan cara menghardik } \\
\text { - mengontrol halusinasi } \\
\text { spongontrol halusinasi } \\
\text { - }\end{array}$ & $\begin{array}{l}\text { S : Senang } \\
\text { O : } \\
\text { - } \text { Pasien mampu mengenali } \\
\text { halusinasi yang dialami nya: isi, } \\
\text { frekuensi, watu terjadi, sruasi } \\
\text { pencetus,perasaan, respon } \\
\text { dengan mandiri } \\
\text { P : } \\
\text { Pasien mampu } \\
\text { halusinasinya dengan cara } \\
\text { menghardik dengan bantuan } \\
\text { - } \\
\text { Latihan } \\
\text { halusinasinya; isi, frekuensi, } \\
\text { watu terjadi, sruasi pencetus, } \\
\text { perasaan dan respon halusinasi } \\
\text { 3x/hari } \\
\text { Latihan menghardik halusinasi } \\
\text { 3x/ hari }\end{array}$ \\
\hline
\end{tabular}




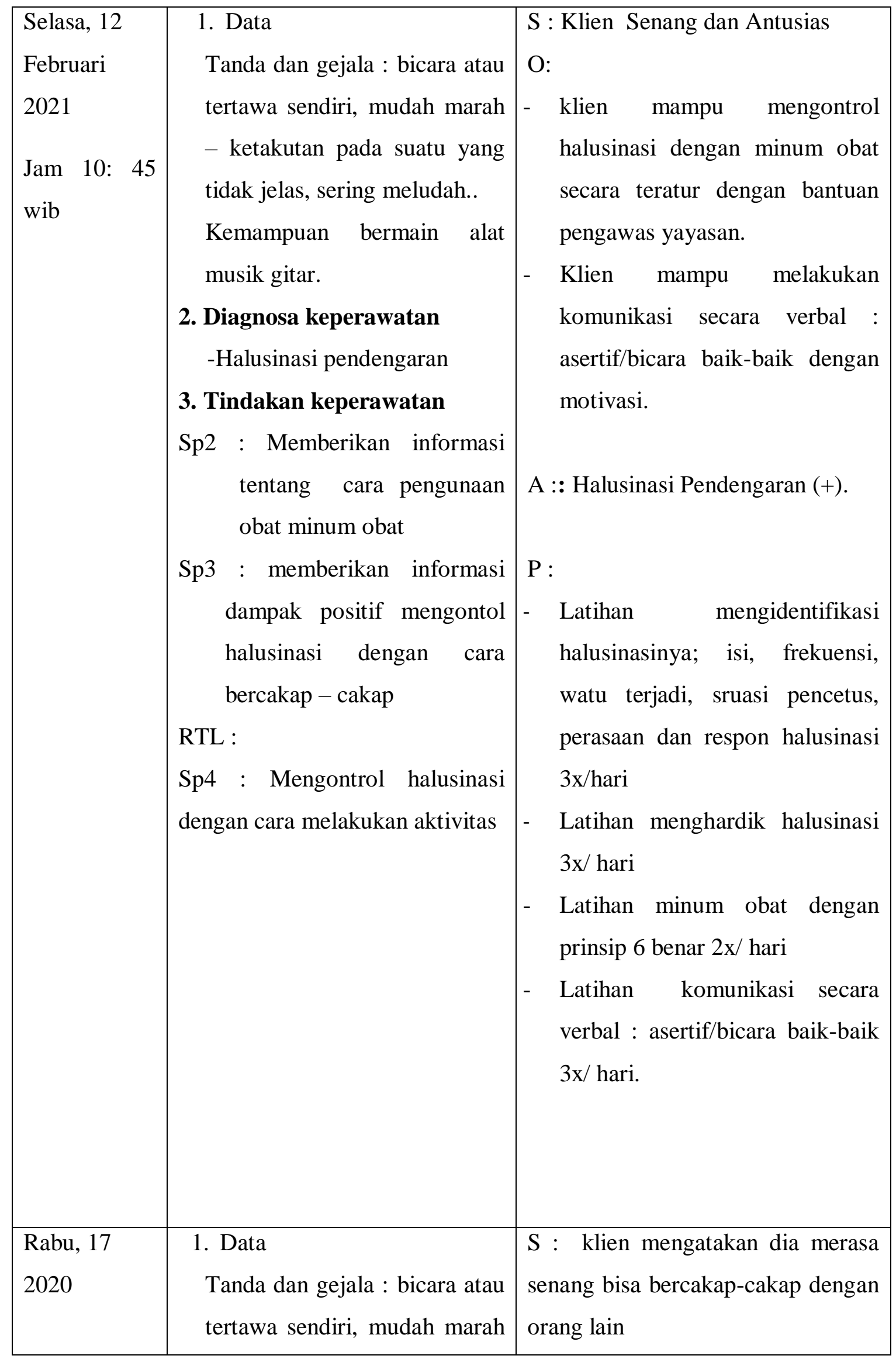




\begin{tabular}{|c|c|c|}
\hline $\begin{array}{l}\text { Jam 10:00 } \\
\text { wib }\end{array}$ & $\begin{array}{l}\text { - ketakutan pada suatu yang } \\
\text { tidak jelas, sering meludah.. } \\
\text { Kemampuan: bermain alat } \\
\text { musik gitar. } \\
\text { 2. Diagnosa keperawatan } \\
\text { Halusinasi } \\
\text { 3. Tindakan keperawatan } \\
\text { Sp4 : Halusinasi } \\
\text { - Mengevaluasi kemampuan } \\
\text { Menghardik Halusinasi } \\
\text { - Melatih pasien untuk } \\
\text { melakukan } \\
\text { spritual dengan cara } \\
\text { berdoa. } \\
\text { - } \\
\text { RTL : } \\
\text { Halusinasi ; : Follow up dan } \\
\text { evaluasi Sp 1-4 Halusinasi }\end{array}$ & $\begin{array}{l}\mathrm{O}: \text { Klien mempraktekkan cara } \\
\text { bercakap-cakap dengan orang lain } \\
\mathrm{A}: \text { Halusinasi pendengaran }(+) \\
\mathrm{P}: \text { Intervensi dilanjutkan } \\
\text { - Latihan menghardik } \\
\text { halusinasi } 3 \mathrm{x} / \text { hari } \\
\text { - Latihan minum obat dengan } \\
\text { prinsip } 6 \text { benar } 2 \mathrm{x} / \text { hari } \\
\text { - Latihan bercakap-cakap } \\
\text { dengan orang lain } 3 \mathrm{x} / \text { hari } \\
\text { - Latihan kegiatan spritual }\end{array}$ \\
\hline
\end{tabular}




\section{BAB 4 \\ PEMBAHASAN}

Setelah penulis melaksanakan asuhan keperawat kepada Ny. L dengan gangguan sensori persepsi: halusinasi pendengaran di Yayasan pemenang jiwa sumatra utara, maka penulis pada $\mathrm{BAB}$ ini akan membahasan kesenjangan antara teoritis dengan tinjauan kasus. Pembahasan dimulai melalui tahapan proses keperawatan yaitu pengkajian, diagnosa keparawatan, perencanaan, pelaksanaan dan evaluasi.

\subsection{Pengkajian}

Pada pembahasan ini diuraikan tentang hasil pelaksanaan tindakan keperawatan dengan pemberian terapi generalis pada klien halusinasi pendengaran. Pembahasan menyangkut analisis hasil penerapan terapi generalis terhadap masalah keperawatan halusinasi pendengaran. Tindakan keperawatan didasarkan pada pengkajian dan diagnosis keperawatan yang terdiri dari tindakan generalis yang dijabarkan sebagai berikut.

Tahap pengkajian pada klien halusinasi dilakukan interaksi perawat-klien melalui komunikasi terapeutik untuk mengumpulkan data dan informasi tentang status kesehatan klien. Pada tahap ini terjadi proses interaksi manusia, komunikasi, transaksi dengan peran yang ada pada perawat sebagaimana konsep tentang manusia yang bisa dipengaruhi dengan adanya proses interpersonal.

Selama pengkajian dilakukan pengumpulan data dari beberapa sumber, yaitu dari pasien dan tenaga kesehatan di ruangan. Penulis mendapat sedikit kesulitan dalam menyimpulkan data karena keluarga pasien jarang mengunjungi pasien di rumah sakit jiwa. Maka penulis melakukan pendekatan kepada pasien melalui komunikasi terapeutik yang lebih terbuka membantu pasien untuk memecahkan perasaannya dan juga melakukan observasi kepada pasien.

Adapun upaya tersebut yaitu: 
a. Melakukan pendekatan dan membina hubungan saling percaya diri pada klien agar klien lebih terbuka dan lebih percaya dengan menggunakan perasaan.

b. Mengadakan pengkajian klien dengan wawancara

c. Mengadakan pengkajian dengan cara membaca status, melihat buku rawatan dan bertanya kepada pegawai ruangan sorik merapi.

Dalam pengkajian ini, penulis menemukan kesenjangan karena ditemukan. Pada kasus Ny. L, klien mendengar suara-suara yang menyuruh untuk melakukan sholat, gelisah, mondar-mandir, tampak tegang, putus asa, sedih dan lain-lain. Gejala gejala yang muncul tersebut tidak semua mencakup dengan yang ada di teori klinis dari halusnasi (Keliat,.2014). Akan tetapi terdapat faktor predisposisi maupun presipitasi yang menyebabkan kekambuhan penyakit yang dialami oleh Ny. L.

Tindakan keperawatan terapi generalis yang dilakukan pada Ny. L adalah strategi pertemuan pertama sampai pertemuan empat. Strategi pertemuan pertama meliputi mengidentifikasi isi, frekuensi, jenis, dan respon klien terhadap halusinasi serta melatih cara menghardik halusinasi. Strategi pertemuan kedua yang dilakukan pada Ny. L meliputi melatih cara mengendalikan dengan bercakap-cakap kepada orang lain. Strategi pertemuan yang ketiga adalah menyusun jadwal kegiatan bersama-sama dengan klien. Strategi pertemuan keempat adalah mengajarkan dan melatih Ny. L cara minum obat yang teratur.

\subsection{Diagnosa Keperawatan}

Pada Teori Halusinasi (NANDA, 2015-2017), diagnosa keperawatan yang muncul sebanyak 3 diagnosa keperawatan (Aji, 2019) yang meliputi:

1. Harga diri rendah

2. Isolasi social

3. Halusinasi 
Sedangkan pada kasus Ny. L ditemukan lima diagnosa keperawatan yang muncul yang meliputi: harga diri rendah, isolasi sosial, halusinasi, koping individu inefektif, regimen teraupetik inefektif. Dari hal tersebut di atas dapat dilihat terjadi kesamaan antara teori dan kasus. Dimana semua diagnosa pada teori muncul pada kasus Ny. L.

\subsection{Implementasi}

Implementasi, adalah tahap dimana perawat memulai melakukan tindakan penulis hanya mengatasi masalah keperawatan halusinasi pendengaran. Dengan melakukan strategi pertemuan yaitu mengidentifikasi isi, frekuensi, waktu terjadi, perasaan, respon halusinasi. Kemudian strategi pertemuan yang dilakukan yaitu latihan mengontrol halusinasi dengan cara menghardik. Strategi pertemuan yang kedua yaitu anjurkan minum obat secara teratur, strategi pertemuan yang ke tiga yaitu latihan dengan cara bercakap - cakap pada saat aktivitas dan latihan strategi pertemuan ke empat yaitu melatih klien melakukankegiatan terjadwal.

\subsection{Evaluasi}

Pada tinajauan teoritis evaluasi yang diharapkan adalah: Pasien mempercayai perawat sebagai terapis, pasien menyadari bahwa yang dialaminya tidak ada objeknya, dapat mengidentifikaasi halusinasi, dapat mengendalikan halusinasi melalui mengahrdik, latihan bercakap-cakap, melakukan aktivitas serta menggunakan obat secara teratur.

Pada tinjauan kasus evaluasi yang didapatkan adalah: Klien mampu mengontrol dan mengidentifikasi halusinasi, Klien mampu melakukan latihan bercakap-cakap dengan orang lain, Klien mampu melaksanakan jadwal yang telah dibuat bersama, Klien mampu memahami penggunaan obat yang benar: 5 benar. Selain itu, dapat dilihat dari setiap evalusi yang dilakukan pada asuhan keperawatan, dimana terjadi penurunan gejala yang dialami oleh Ny. L dari hari kehari selama proses interaksi. 


\section{BAB V \\ PENUTUP}

\subsection{Kesimpulan}

Berdasarkan uraian pada pembahasan di atas, maka penulis dapat disimpulkan bahwa:

1. Pengkajian dilakukan secara langsung pada klien dan juga dengan menjadikan status klien sebagai sumber informasi yang dapat mendukung data-data pengkajian. Selama proses pengkajian, perawat mengunakan komunikasi terapeutik serta membina hubungan saling percaya antara perawat-klien. Pada kasus Ny. L, diperoleh bahwa klien mengalami gejala-gejala halusinasi seperti mendengar suarasuara, gelisah, sulit tidur, tampak tegang, mondar-mandir,tidak dapat mempertahankan kontak mata, sedih, malu, putus asa, menarik diri, mudah marah dan lain-lain. Faktor predisposisi pada Ny. L yaitu pernah mengalami gangguan jiwa sebelumnya serta memiliki riwayat mengonsumsi alkohol dan obat terlarang.

2. Diagnosa keperawatan yang muncul pada kasus Ny. L: Halusinasi pendengaran, isolasi sosial, koping individu inefektif, regimen teraupetik keluarga inefektif, harga diri rendah serta keputusasaan. Tetapi pada pelaksanaannya, penulis fokus pada masalah utama yaitu halusinasi pendengaran.

3. Perencanaan dan implementasi keperawatan disesuaikan dengan strategi pertemuan pada pasien halusinasi pendengaran dan harga diri.

4. Evaluasi diperoleh bahwa terjadi peningkatan kemampuan klien dalam mengendalikan halusinasi yang dialami serta dampak pada penurunan gejala halusinasi pendengaran yang dialami. 


\subsection{Saran}

1. Bagi Perawat

Diharapkan dapat menerapkan komunikasi terapeutik dalam pelaksanaan strategi pertemuan 1-4 pada klien dengan halusinasi sehingga dapat mempercepat proses pemulihan klien.

2. Bagi Institusi Pendidikan

Dapat meningkatkan bimbingan klinik kepada mahasiswa profesi ners sehingga mahasiswa semakin mampu dalam melakukan asuhan keperawatan pada pasien-pasien yang mengalami halusinasi pendengaran

3. Bagi Tempat

Laporan ini diharapkan dapat menjadai acuan dan referensi dalam memberikan asuhan keperawatan pada klien dengan halusinasi pendengaran. 


\section{DAFTAR PUSTAKA}

Aji, W. M. H. (2019). Asuhan Keperawatan Orang Dengan Gangguan Jiwa Halusinasi Dengar Dalam Mengontrol Halusinasi. https://doi.org/10.31219/osf.io/n9dgs

Anggraini, T \& Maula, (2021). Asuhan Keperawatan Jiwa Pada An S Dengan Gangguan Persepsi Sensori Halusinasi Pendengaran. Karya Tulis Ilmiah, Universitas Kusuma Husada Surakarta. http://eprints.ukh.ac.id/id/eprint/1510/1/NASKAH\%20PUBLIKASI\% 20TITANIA\%20ANGGRAINI.pdf

Damaiyanti \& Iskandar. (2014). Asuhan Keperawatan Jiwa. Bandung : Refika Aditama. http://repository2.unw.ac.id/id/eprint/102

Hernandi, B. (2020). Penerapan Aktivitas Terjadwal Pada Klien Dengan Gangguan Halusinasi Di Wilayah Kerja Puskesmas Godean 1 Skripsi, Poltekkes Kemenkes Yogyakart. http://eprints.poltekkesjogja.ac.id/id/eprint/2581

Keliat B,. (2014). Proses Keperawatan Jiwa Edisi II. Jakarta : EGC.

Keliat, Budu A. (2011). Keperawatan Kesehatan Jiwa Komunitas. EGC, Jakarta.

Keliat, B.A \& Akemat. (2012). Model Praktik Keperawatan Profesional Jiwa. Jakarta:EGC.

Kemenkes RI. (2019). Riset Kesehatan Dasar, Riskesdas.Jakarta: Kemenkes RI.https://databoks.katadata.co.id/datapublish/2019/10/08/persebaranprevalensi-skizofreniapsikosis-di-indonesia

Manao, B. M., \& Pardede, J. A. (2019). Beban Keluarga Berhubungan Dengan Pencegahan Kekambuhan Pasien Skizofrenia. Jurnal Keperawatan Jiwa, 12(3).

Mubarta, AF . (2011). Gambaran Distibusi Penderita Gangguan Jiwa di Wilaya Banjarmasin dan Banjarbaru. Tesis. http://dx.doi.org/10.33757/jik.v1i1.29

Mubin, M. F \& P. H. Livana. (2019). Hubungan Kepatuhan Minum Obat Dengan Kekambuhan Pasien Skizofrenia Paranoid." Jurnal Farmasetis (8).1 https://doi.org/10.32583/farmasetis.v8i1.493

Nyumirah, S. (2013). Peningkatan kemampuan interaksi sosial (kognitif, afektif dan perilaku) melalui penerapan terapi perilaku kognitif di $r s j \mathrm{dr}$ amino gondohutomo semarang. Jurnal keperawatan jiwa, I(2).. https://doi.org/10.26714/jkj.1.2.2013.\%25p 
Oktiviani, D. P. (2020). Asuhan Keperawatan Jiwa Pada Tn. K dengan masalah Gangguan Persepsi Sensori: Halusinasi Pendengaran di Ruang Rokan Rumah Sakit Jiwa Tampan. Skripsi, Poltekkes Kemenkes Riau. http://repository.pkr.ac.id/id/eprint/498

Pardede, J. A., \& Hasibuan, E. K. (2019). Dukungan Caregiver Dengan Frekuensi Kekambuhan Pasien Skizofrenia. Idea Nursing Journal, 10(2). http://e-repository.unsyiah.ac.id/INJ/article/view/17161

Pardede, J. A., Keliat, B. A., \& Yulia, I. (2015). Kepatuhan dan Komitmen Klien Skizofrenia Meningkat Setelah Diberikan Acceptance And Commitment Therapy dan Pendidikan Kesehatan Kepatuhan Minum Obat. Jurnal Keperawatan Indonesia, 18(3),157-166. http://dx.doi.org/10.7454/jki.v18i3.419

Satria F. S.A \& Ice Y. W. (2019). Efektivitas Penerapan StandarAsuhan Keperawatan Jiwa Generalis Pada Pasien Skizofrenia Dalam Menurunkan Gejala Halusinasi. http://jurnal.unimus.ac.id/index.php/JKJ/article/view/4855/pdf

Stuart, G. W. (2013). Buku Saku Keperawatan Jiwa . Edisi 5. Jakarta. EGC.

Townsend, M. C. (2014). Psychiatric Mental Healt Nursing : Concepts of Care in Evidence-BasedPractice(6thed.), Philadelphia: F.A. Davis. https://books.google.co.id/books?hl=id\&lr=\&id=3a0-

Yosep I. (2011). Keperawatan Jiwa (Edisi Revisi). Bandung: Refika Aditama http://repository.um-surabaya.ac.id/id/eprint/3356

Yusuf, A. (2015). Buku Ajar Keperawatan Kesehatan Jiwa. Jakarta Salemba Medika. 